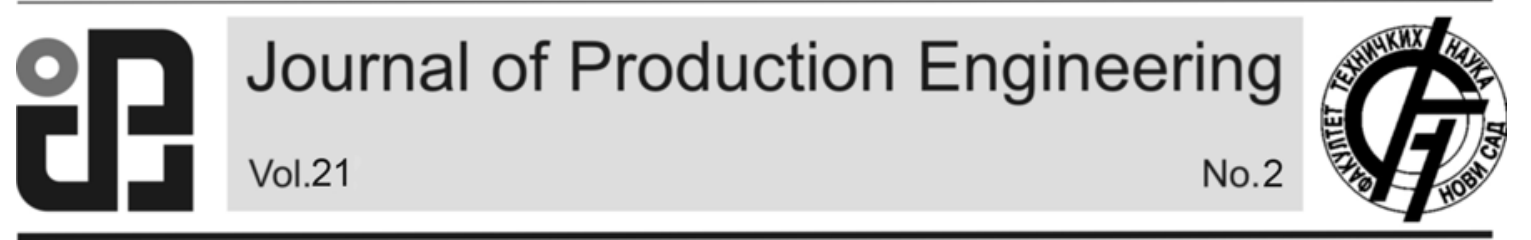

JPE (2018) Vol.21 (2)

Original Scientific Paper

Kareem, B., Ewetumo, T., Adeyeri, M.K., Oyetunji, A, Olowookere, S.T.

\title{
DEVELOPMENT OF ELECTRICITY GENERATING SYSTEM FOR A MICRO- POWER PLANT
}

Received: 07 August 2018 / Accepted: 17 November 2018

\begin{abstract}
The move from fossil fuel to clean energy has become the focus of the $21^{\text {st }}$ century, to suplement the energy needs of the world which have been on the increase. This research tackles the challenge of energy inadequacy by designing and fabricating electric generator for micro-power plant using locally sourced materials. The design of the $5.5 \mathrm{~kW}$ induction generator involved the application of recycling technique on the discarded scrap motor. Discarded electric motor after cleaning was redesigned and rewound to give an electric power output of 5.5 $k W$. The generator was tested under load and no load conditions. The outcomes showed that the generator can adequately carry a load of $2.3 \mathrm{~kW}$ when operated at speed ranging between 2300 and $2400 \mathrm{pm}$. The output voltage ranging between $150 \mathrm{~V}$ and $190 \mathrm{~V}$, while the ouput current was in the range $6.07 \mathrm{~A}$ and $6.35 \mathrm{~A}$. Higher load carrying capacity, $5.0 \mathrm{~kW}$ was achievable at the rotory design speed, $3000 \mathrm{rpm}$ with the maximum voltage and current limits, $239.6 \mathrm{~V}$ and $10.467 \mathrm{~A}$, respectively. The 3-phase induction generator was able to sustain higher power output, $5.0 \mathrm{~kW}$ of the design capacity.
\end{abstract}

Key words: Electric generator, Micropower plant, Clean energy, Recycling, Palm Kernel Shell (PKS)

Razvoj sistema za proizvodnju električne energije kod mikro-elektrana. Prelazak sa fosilnih goriva na čistu energiju postao je u fokusu 21. veka, kako bi dopunili energetske potrebe sveta koji su u porastu. Ovo istraživanje se bavi izazovom neadekvatne energije projektovanjem $i$ proizvodnjom električnog generatora za mikroelektranu koristeći lokalno nabavljene materijale. Dizajn generatora indukcije $5.5 \mathrm{kV}$ uključivao je primenu tehnike reciklaže na odbačenom motornom otpadu. Otpadni elektromotor nakon čišćenja je redizajniran i preusmeren da daje električnu snagu od 5,5 kV. Generator je testiran pod opterećenjem i bez opteréenja. Ishodi su pokazali da generator može adekvatno nositi opterećenje od 2,3 kV kada se koristi na brzini od 2300 do 2400 obrtaja u minuti. Izlazni napon se kreće između $150 \mathrm{~V}$ i $190 \mathrm{~V}$, dok je struja napona bila u opsegu 6.07A i 6.35A. Veća nosivost nosivosti, 5,0 kV je postignuta na rotacionoj brzini dizajna, 3000 obrtaja u minuti sa maksimalnim naponskim $i$ strujnim granicama, 239,6 V i 10,467 A, respektivno. Trofazni indukcioni generator je mogao održavati veću izlaznu snagu, 5,0 kV od projektovanog kapaciteta.

Ključne reči: Električni generator, Mikro-Elektrana, Čista energija, Reciklaža, Palm Kernel Shell (PKS)

\section{INTRODUCTION}

Electricity is important to human economic activity as oxygen is to human existence. Dependence on electric power has been on the rise since the industrial revolution with the most of it generated from fossil fuels. Whitney [1] defines fossil fuels as energy-rich substances that have formed from long-buried plants and microorganisms. It includes petroleum, coal, and natural gas which provide most of the energy that powers modern industrial society. The negative effects of fossil fuel consumption is a major reason for research into alternative ways of power generation. Acid rain and global warming are two of the most serious environmental issues related to large-scale fossil fuel combustion. Other environmental problems, such as land reclamation and oil spills, are also associated with the mining and transporting of fossil fuels [1].

There are currently two main types of power plants operating in Nigeria: hydro-electric and thermal or fossil fuel power plants. With a total installed capacity of $8457.6 \mathrm{MW}$ in early 2014 , thermal power plants (coal or gas-fired plants) dominates the Nigerian power supply mix [2]. With the increasing population of
Nigeria, one of the ways of solving the power supply problem is the creation of micropower plants that are renewable energy based [3, 4, 5, 6, 7]. Renewable energy is also known as alternative energy, is generally a form of energy that are not based on fossil fuels which are renewable and sustainable [8]. Biomass, as an example of renewable energy is being measured based on energy conversion from dry weight of a tree's leaves, branches, stem (trunk), and roots $[9,10,11]$. In the production of palm oil, biomass residues can be converted to useful fuel for steam and electricity generation [12, 13]. In Nigeria, palm oil accounts for about $1.5 \%$ (930,000 metric tonnes) of the global output. A huge quantity of oil palm residues that came from palm oil processing could be converted to electric energy [9, 11] from which up to 20 - 35 MW of electricity could be generated. This can significantly reduce greenhouse gases and creating employment opportunities for the local population through sprout of small scale industries $[13,14,15]$.

Generation of electricity involves combustion, the production of heat, conversion of heat energy to electric power. A typical power plant consists of a heat source, working fluid and generator that converts from 
mechanical energy to heat energy, then electric power. Palm kernel shells is usable as heat source. Oladosu et al. [12] designed a CAD program that was used to design a palm kernel shell combusting furnace using standard design equations to size the furnace and its components. They were able to get results that enabled generation of $5 \mathrm{~kW}$ of electricity from palm kernel shell using the data: $5.5 \mathrm{~kW}$ turbine, $3.1 \mathrm{~m}$ superheater, $3.8 \mathrm{~m}$ riser, furnace of $1.432 \mathrm{~m}$ height and $0.45 \mathrm{~m}^{3}$ volume. The results were also used to size the appropriate boiler for the generation process. The power station of a power system consists of a prime mover, such as a turbine driven by water, steam, or combustion gases that operate a system of electric motors and generators. The scope of their study was limited to design, practical aspects were neglected. Micro-power plants are known to be auxiliary sources of power (less than $100 \mathrm{~kW}$ ) that support the main generation from the power grid. They are mostly used in the renewable energy sector where input and output can vary and be small, The types of turbines used may vary based on the type of primary fuel or energy source [16].

Generators are a vital part of electricity generation, they are the devices used to convert the mechanical energy from the prime mover to electrical energy. It works on the principle of electromechanical energy conversion which takes place through magnetic or electric field medium which is created in the coils contained in the generator. A Generator is mainly composed of two major parts, the stator and the rotor. It produces electricity when a conductor, such as a wire, moves through the gap between the poles of a magnet. This creates a potential difference, or voltage, between the ends of the wire. If the ends of the wire are connected by a conductor, a current will flow around the circuit $[8,17]$. There are two major types of generators used in electricity generation, the synchronous and the asynchronous. The selection of the most preferred informed the design and fabrication of the generator that capable of producing a $5.5 \mathrm{~kW}$ electric power.

The process of electricity generation through a steam turbine as the prime mover involves high speed and high torque that can be efficiently achieved through right choice of generator to mitigate costly nature of setting up a micro power plant. There is need to design a $5.5 \mathrm{~kW}$ generator that would be made from locally sourced materials to guard against highly dependence on overseas for spare parts. The aim of the research is to design, fabricate and evaluate an efficient $5.5 \mathrm{~kW}$ rating generator for a micro power plant to generate $5.0 \mathrm{~kW}$ of electricity. The target is to establish a foundation for the production of generators for micro power plants from locally sourced materials, which will serve as basis of developing a system for large-scale production of electicity.

Addressing the lack of access to energy is a key policy priority, and many developing countries have begun to implement policies and programs to expand the development of their energy resources, including by attracting investment to small-scale or renewable power generation projects. Small-scale projects are often the only option for providing power to remote sites or in areas with low or diffuse demand, but they are often more expensive than larger projects (per unit of energy generated) and are not necessarily the most effective use of resources for a national utility company [15, 18]. Nevertheless, they are very good options for providing electricity to rural areas and supplementing the national grid, in addition to the use of renewable energy [9, 19, $20,21]$. Production of electricity from renewable energy (wind, solar, biomass as in palm kernel shell) most times rely on electromechanical generators for the final stage of conversion from mechanical to electrical energy [9, 22, 23]. Generators can be classified into AC generators and DC generators. AC Generators are also known as alternators. It works based on the principle of electromagnetic induction. Azhumakan et al. [5], concluded that the use of asynchronous generators is more appropriate because they satisfy requirements of high-quality voltage, low mass, relatively low cost, high reliability, simple design and an easy maintenance. Upadhayay [20] in evaluating the effectiveness of micro-hydropower plant discovered that asynchronous generators are preferable because they have ability to operate at different speeds with a constant frequency. Reduction in costs per unit, durability, reduced size, lack of separate DC power supply, ease of maintenance, self-protection against the severe overloads and short circuits are the key advantages of the asynchronous generators [6, 14, 24]. An inverted design, where a rotor with the excitation winding is a motionless and the stator rotates, is rare in the synchronous machines [7, 25, 26]. Generation by Synchronous generators for a micro power plant is a complex task [5]. The characteristic feature of the asynchronous generator (AG) is their ability to produce the magnetizing current for the magnetic fields formation. When operating in the generator mode, the asynchronous machine consumes the reactive power from the network and gives the reactive power to the load. The simplest Electromagnetic Generator (EMG) is an asynchronous self-excited generator (ASG), which is three-phase with the rotor and excitation condensers connected parallel to the stator. Until recently the application of ASG was restrained by failed external characteristics of the engine and absence of reliable and cheap source of reactive power. Modern achievements in the field of condenser construction, semiconductor techniques and electronics, which allowed reduction in weight, size and cost of AC condensers, set the stage for the successful solution of problems of ASG application. Comparative evaluations of weight, size and energy performance of asynchronous and synchronous generators in the power range of $1-100 \mathrm{~kW}$ at a frequency of $50 \mathrm{~Hz}$ and a speed of $3000 \mathrm{rpm}$ showed that the total weight of $\mathrm{AG}$ together with the excitation device is less than the SG by 1.3-1.4 times. Compared with the non-contact $\mathrm{SG}$ (inductor), the mass of $\mathrm{AG}$ is less by 2-3 times $[5,26]$.

\section{MATERIALS AND METHODS}

The induction generator was designed to be selfinduced using the capacitance. The generator was made up of two major parts, the rotor and the stator. The design of the induction generator involved the 
calculation of the parameters that transformed the 6.8 $\mathrm{kW}$ scrap induction generator into the working generator of $5.5 \mathrm{~kW}$ output. The specifications of the scrap and the newly produced generator are given in Table 1, which served as basis for the redesign.

\begin{tabular}{|l|l|l|}
\hline \multicolumn{1}{|c|}{ Specifications } & Available & \multicolumn{1}{|c|}{ New design } \\
\hline $\begin{array}{l}\text { Type of } \\
\text { Generator }\end{array}$ & $\begin{array}{l}\text { Scrap } \\
\text { Induction } \\
\text { generator }\end{array}$ & $\begin{array}{l}\text { Asynchronous } \\
\text { or Induction } \\
\text { generator }\end{array}$ \\
\hline $\begin{array}{l}\text { Method of } \\
\text { excitation }\end{array}$ & - & Capacitor banks \\
\hline Power Output & $6.8 \mathrm{~kW}$ & $5.5 \mathrm{~kW}$ \\
\hline $\begin{array}{l}\text { Number of } \\
\text { phases }\end{array}$ & 3 -phase & 3 -phase \\
\hline No of poles & 4 poles & 4 poles \\
\hline No of slots & 38 slots & 38 slots \\
\hline Power factor & - & 0.86 \\
\hline Efficiency & - & $85 \%$ \\
\hline
\end{tabular}

Table 1. Design specifications of the induction generator

\subsection{Design calculations}

AC motor units were constructed with two or four poles. A magnetic field was created in the stator poles that induced magnetic fields on the rotor. The driving force of the electric motor is torque. The rotor rotation was slower than the magnetic field of the stator. The difference between the synchronous speeds of the stator and the actual operating speed is called slip [8]. Synchronous speed $\left(\mathrm{N}_{\mathrm{S}}\right)$ is the speed at which the magnetic field rotates $[27,28]$. It is dependent on motor design, and was designed to be $1500 \mathrm{rpm}$.

The power produced by the motor depends on the speed $[27,28]$. The torque $(\mathrm{T})$ of the motor was estimated to be $3.57 \mathrm{kgm}$. Power (W) in the electric circuit is the rate of flow of energy. Apparent power is measured in volt-amperes (VA). Reactive Power (VAR) is power stored in and discharged by inductive motors, transformers and solenoids [27, 29]. Using standard formulae [27, 30], apparent power, reactive power, phase angle and real power were estimated as $6.4 \mathrm{kVA}, 3.263 \mathrm{kVAR}, \quad 30.68^{\circ}$ and $5.5 \mathrm{kVA}$ respectively using power factor 0.86 .

Three-phase electricity consists of three $\mathrm{AC}$ voltages of identical frequency and similar amplitude. Each AC voltage phase was separated by $120^{\circ}$ [31]. The 3 -phase circuit was connected in star or wye, with a common point called the neutral. The fourth neutral wire was used to carry the resultant current [29]. The sum of the three $120^{\circ}$ phase shifted voltages at any instant is zero [29]. The phase and line voltage of the designed alternator/generator, $\mathrm{V}_{\mathrm{ph}}(239.6 \mathrm{~V})$ was estimated [28]. Based on standard formulae [32], current of 10.467A was computed. In order to generate the required electricity, the capacitor must be connected to the winding of generator. The capacitors served as the excitation source for the induction generator [25]. This was established from equation (1) as follows.

$C(F)=\frac{1000 * Q(k V A R)}{3 * 2 \pi f * V_{p h}^{2}}$

$$
\begin{aligned}
& C(F)=\frac{1000 * 3.263}{3 * 2 * \pi * 50 * 239.6^{2}} \\
& C(F)=60.307 \mu F
\end{aligned}
$$

Increased in number of coils led to increased generated electromotive force (EMF). The number of turns needed to get the desired output of $5.5 \mathrm{~kW}$ was gotten over the available specifications of the $6.8 \mathrm{~kW}$ induction generator.

$$
\begin{aligned}
& \text { Number of turns }=\frac{\text { phase voltage }}{E_{o}} \\
& E_{o}=L * B * 4.44 * 1.02 * f * 10^{-6} \\
& L, \text { is the length of stator, } 220 \mathrm{~mm} \\
& B \text {, is the breadth or diameter of stator, } 190 \mathrm{~mm} \\
& f \text {, frequency, } 50 \mathrm{~Hz} \\
& E_{o},=9.465192
\end{aligned}
$$

Phase voltages for each phase and colour coding were:

Phase $1(\mathrm{~L} 1)=220 \mathrm{~V}$ Red

Phase $2(\mathrm{~L} 2)=230 \mathrm{~V}$ Yellow

Phase $3(\mathrm{~L} 3)=240 \mathrm{~V}$ Blue

Number of turns for $\mathrm{L} 1=\frac{220}{9.465192}=23$ turns

Number of turns for L2 $=\frac{230}{9.465192}=24$ turns

Number of turns for L3 $=\frac{240}{9.465192}=25$ turns

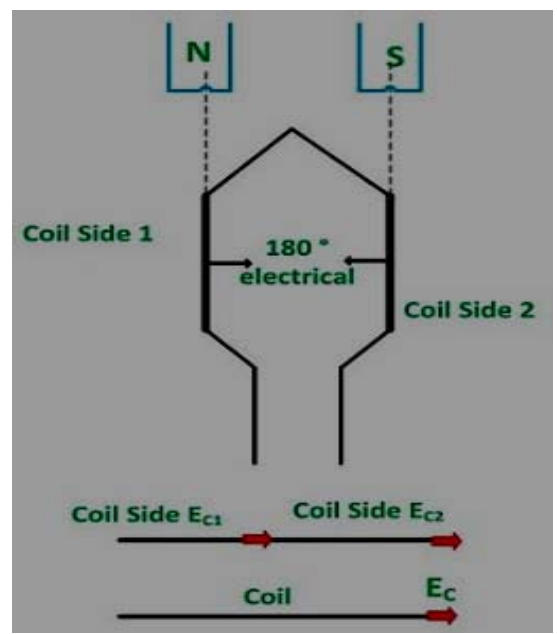

Fig. 1. A coil having a span equal to 180 electrical degrees (full pitch coil)

Coil of the rotating engine (Fig. 1) was made up of multi turns of the conductor. In multi turns coil, there were multiple conductors per side of the coil. The pole pitch is defined as the peripheral distance between centres of two adjacent poles in the rotating generator. The distance was measured in term of armature slots or armature conductor between two adjacent pole centres. Pole pitch is equal to the total number of armature slots divided by the number of poles in the generator. For the 96 slots on the armature periphery and 4 numbers of poles in the generator, the numbers of armature slots come between two adjacent poles centres was 96/4 (24). 
The pole pitch is equal to total numbers of armature slots divided by the total number of the poles [33]. The following data were used to get the winding configurations from the standard relations $[8,34]$.

Number of slot $=38$ (36 used, 2 unused)

Number of poles $=4$

Number of phases $=3$

Coil span $=9$ slots

Slot angle $=\frac{180^{\circ}}{9}$

Slots per pole per phase $=3$

Phase difference $=6$

The winding configuration for the coil sets for each of the phases based on the slot per pole per phase is shown in Table 2. In lap winding, the coil sets were connected in start to start and in finish to finish.

\begin{tabular}{|l|c|c|c|c|}
\hline Phase & Pole 1 & Pole 2 & Pole 3 & Pole 4 \\
\hline $\mathrm{R}$ & $1,2,3$ & $10,11,12$ & $19,20,21$ & $28,29,30$ \\
\hline $\mathrm{Y}$ & $7,8,9$ & $16,17,18$ & $25,26,27$ & $34,35,36$ \\
\hline $\mathrm{B}$ & $13,14,15$ & $22,23,24$ & $31,31,33$ & $4,5,6$ \\
\hline
\end{tabular}

Table 2. Winding configurations for the coil sets and phases for the generator

Torque is transmitted from the palm kernel shell fuelled steam turbine (petrol engine) to the alternator (electric generator) by coupling. Slip can be defined as the difference between the flux speed (Ns) and the rotor speed $(\mathrm{N})$. The speed of the rotor was expressed as a percentage of synchronous speed (Ns). Since the synchronous speed of the alternator is $1500 \mathrm{rpm}$, it has to be driven at a speed higher than $1500 \mathrm{rpm}$ to allow for the slip to be negative [34]. Hence,

Speed of the prime mover $=$ synchronous speed $+\%$ slip speed.

Speed of the prime mover $=1500+\%$ slip speed

Minimum requirements for the prime mover $(5.5 \mathrm{~kW}$ steam turbine/13 HP petrol engine) was adopted for the peformance evaluation of the generating system.

$\operatorname{Power}(\mathrm{kW})=H P * 746=9.698 \mathrm{~kW}$

The torque needed for the induction generator was $35.014 \mathrm{Nm}(3.57 \mathrm{kgm})$. By taking the slip of the coupling as $-3 \%$, the speed of the engine was estimated as,

$\%$ slip $=\frac{N_{s}-N}{N_{s}} * 100$

$N=1545 \mathrm{rpm}$

The torque generated by the prime mover with output power $\mathrm{P}, 9.698 \mathrm{~kW}$ and speed $\mathrm{N}, 1545 \mathrm{rpm}$ is:

$T=\frac{60}{2 \pi} * \frac{P-1000}{N}$

$T=59.941 \mathrm{Nm} \approx 6.11 \mathrm{kgm}$

The design configuration of the induction generator with major components is given in Fig. 2.

The process of rewinding/redesigning involved the following steps. First, the coils from the scrap induction generator were removed while the data including the number of slots and the number of poles were recorded for use in designing for the $5.5 \mathrm{~kW}$ induction generator (Fig. 3). Second, burning and cleaning of slots using a blowtorch was carried out. Third, winding of stator and rotor coils based on the design calculations was done. Fourth, the insulation papers were fixed in the slots, the stator was wound based on the slot configuration and the number of turns as designed. Fifth, the ends are soldered start to start and finish to finish (Figs 4 and 5). Last, turning of the shaft on the lathe to the designed size for the recalibration purpose was carried out (Figs. 6 and 7). The complete assembly of the fabricated components are shown in Fig. 8.

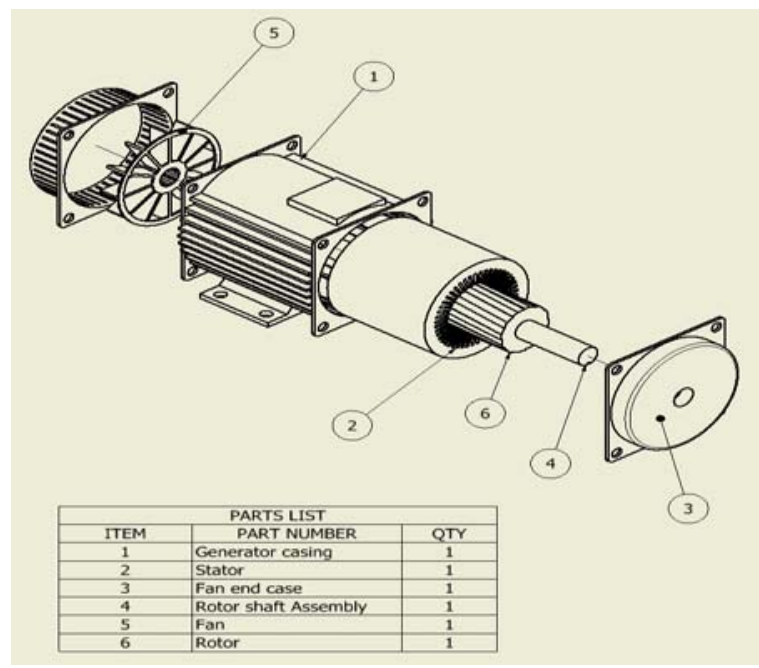

Fig. 2. An exploded view of the Induction generator.

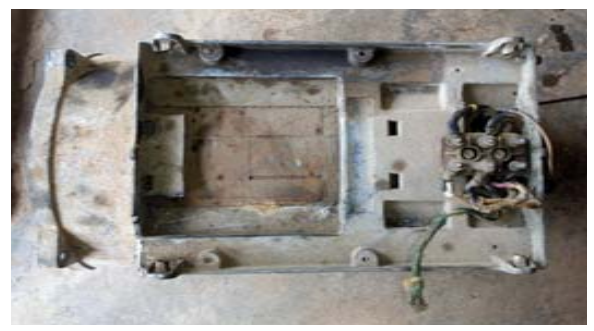

Fig. 3. The scrap induction generator

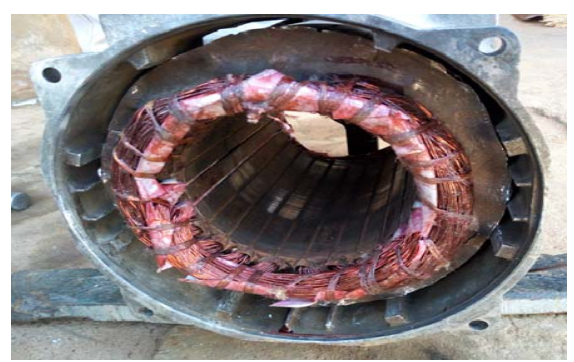

Fig. 4. The stator after rewinding and varnishing

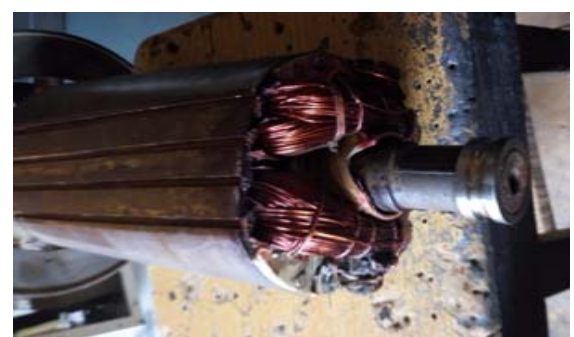

Fig. 5. The rotor after rewinding and varnishing 


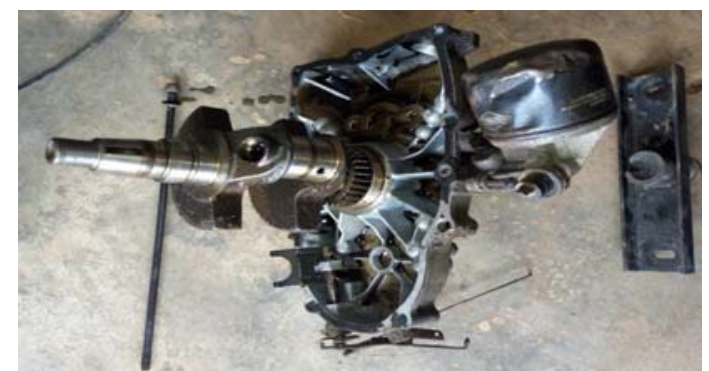

Fig. 6. Shaft configuration before turning operation

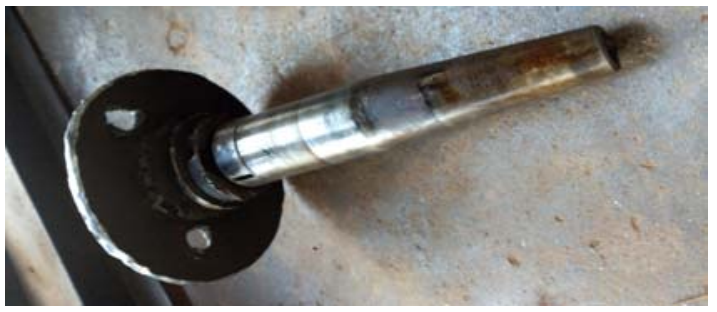

Fig. 7. Shaft geometry after turning operation

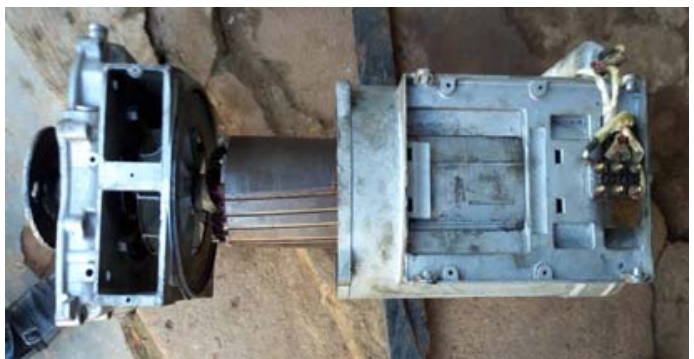

Fig. 8. Assembly of all the generator components

The materials used for the generator components were classified into consumable and non-consumables. Consumable materials were applied in the process of design and production of the generator, while the nonconsumables were used during testing process of the generator. Consumable materials include the following: insulation paper, which was the primary layers of insulation in motor coils and they are inserted in motor winding to separate each of the winding coils from another. Paper insulation was used because of its proven durability at high voltages. Diodes in the system allow the flow of current in one direction. Motor varnish (windings immobilizer) was the second layer of insulation applied to the coils on the rotor and stator windings. The appropriate winding wire size and the number of turns were selected based on the design and physical space available on the discarded motor. This choice was based on; the performance requirements of the design (speed, acceleration, power consumption, cost, etc.), and constraints on the maximum amperage a particular wire size and electrical insulation can survive. Hence, SWG $22(0.711 \mathrm{~mm})$ was chosen for the generator. Sandpaper was used to remove the coatings from the copper wire windings. Insulation sleeves of fibre type were used to insulate wires, provide abrasion resistance and environmentally protect the stranded and solid wire. Cotton thread was applied to hold the windings firmly in place and hence enabled orderliness and neatness.

Non-consumable materials include the following: Nose plier was used to cut and bend small wires and electrical wiring. Spanner provided grip and mechanical torque to turn rotary fasteners, bolts and nuts during assembly process. Oil can was a tool used for system lubrication. Mallet was applied softly and safely to put the rotor, windings or coils in place. Wire gauge (micrometer) was for certifying and ascertaining the wire diameter of the copper windings before the application of the adjustable cutter.

Engineering materials were selected with the main objective of minimizing cost of producing the generator. Factors considered in material choice were service life, lightweight, corrosion resistance and durability. The materials selected based on the design calculations are given in the Table 3 . Table 4 shows the bill of materials with respect to the fabricated and tested generator.

\begin{tabular}{|l|l|l|l|l|}
\hline $\begin{array}{l}\text { Machine } \\
\text { component }\end{array}$ & Criteria for selection & $\begin{array}{l}\text { Material Used for } \\
\text { The design }\end{array}$ & Material suitable & $\begin{array}{l}\text { Reasons for } \\
\text { Material selection }\end{array}$ \\
\hline Stator & $\begin{array}{l}\text { Strength, } \\
\text { machinability, cost, } \\
\text { ailability, stability }\end{array}$ & Silicon steel & $\begin{array}{l}\text { Silicon steel, mild steel, } \\
\text { cast iron }\end{array}$ & $\begin{array}{l}\text { Strength, low } \\
\text { cost, } \\
\text { machinability }\end{array}$ \\
\hline Rotor & $\begin{array}{l}\text { Strength, } \\
\text { machinability, cost, } \\
\text { availability, stability }\end{array}$ & Silicon steel & $\begin{array}{l}\text { Silicon steel, mild steel, } \\
\text { cast iron }\end{array}$ & $\begin{array}{l}\text { Strength, low } \\
\text { cost, } \\
\text { machinability }\end{array}$ \\
\hline Shame & $\begin{array}{l}\text { Weldability, } \\
\text { machinability, surface } \\
\text { finish, cost, strength }\end{array}$ & Mild steel & $\begin{array}{l}\text { Mild steel, aluminium, } \\
\text { stainless steel }\end{array}$ & $\begin{array}{l}\text { Welding } \\
\text { ability, cost } \\
\text { strength }\end{array}$ \\
\hline Bearing & $\begin{array}{l}\text { High torsional rigidity, } \\
\text { high fatigue resistance } \\
\text { cost }\end{array}$ & high strength steel & $\begin{array}{l}\text { high strength steel, } \\
\text { aluminium alloy, titanium } \\
\text { and magnesium alloy }\end{array}$ & $\begin{array}{l}\text { Strength, type of } \\
\text { load and } \\
\text { resistance }\end{array}$ \\
\hline Outer case & $\begin{array}{l}\text { Corrosion resistance, } \\
\text { lightness, surface finish, } \\
\text { cost }\end{array}$ & Galvanized steel & $\begin{array}{l}\text { Gall bearing Roller } \\
\text { steel, mild steel }\end{array}$ & Cost, type of load \\
\hline
\end{tabular}

Table 3. Material choice and reasons for selection 


\begin{tabular}{|l|l|l|}
\hline $\mathrm{S} / \mathrm{N}$ & Material & Cost $(\mathrm{N})$ \\
\hline 1 & Induction generator & 135,000 \\
\hline 2 & Design & 15,000 \\
\hline 3 & Frame of generator & 10,000 \\
\hline 4 & Painting & 3,000 \\
\hline 5 & Engine rest bed & 20,000 \\
\hline 6 & Petrol engine & 47,000 \\
\hline 7 & Coupling & 5,000 \\
\hline 8 & Transportation & 15,000 \\
\hline 9 & Miscellaneous & 5,000 \\
\hline & Total (in Naira, N) & 255,000 \\
\hline & Total (in USD, \$) & $\$ 700$ \\
\hline
\end{tabular}

Table 4. Bill of engineering measurements and evaluation

The process of testing the induction generator was to ascertain if the output at the main, upon connection to a prime mover, is the same, higher or at least close to those calculated. Some of the parameters tested include the generator speed on and without load, the output voltage across the lines and phases, the output current across the lines and phases, the torque and the continuity of the generation. Some of the instruments used are: tachometer (sensor device used to measure the rotation speed (rpm) of the generator); digital multimeter (tool for measuring voltage and current); and wattmeter (for measuring the electric power). The voltage testing process is illustrated in Fig. 9. The tests carried out on the alternator (generator) comprised noload and on load tests. The behaviour of the alternator under load was observed and recorded. The chosen load were sum up to $2.3 \mathrm{~kW}$. The load was connected to the phase 3 of the alternator. The parameters noted were the load and no-load speeds, and the load and no-load voltage. Tests were carried out at two different periods of 13.00 GMT and 19.00 GMT of the same day in step of 20 minutes intervals. Tests were carried out in four replicates.

\section{RESULTS AND DISCUSSION}

Table 5 contains the design specifications of the fabricated induction generator and the minimum requirements for the prospective prime mover. The outcome showed that to generate $5 \mathrm{~kW}$ of electricity minimum power, starting torque and speed required were $5.5 \mathrm{~kW}, 35.014 \mathrm{Nm}$, and $1500 \mathrm{rpm}$ respectively.

\begin{tabular}{|l|l|}
\hline Type of Generator & $\begin{array}{l}\text { Asynchronous or } \\
\text { Induction generator }\end{array}$ \\
\hline Method of excitation & Capacitor banks \\
\hline Power Output starting & $5.5 \mathrm{~kW}, 6.4 \mathrm{kVA}$ \\
\hline $\begin{array}{l}\text { Minimum } \\
\text { Torque }\end{array}$ & $35.014 \mathrm{Nm}$ (3.57 Kgm) \\
\hline Number of phases & 3-phase \\
\hline No of poles & 4 poles \\
\hline No of slots & 38 slots \\
\hline Power factor & 0.86 \\
\hline Synchronous speed & $1500 \mathrm{RPM}$ \\
\hline Efficiency & $85 \%$ \\
\hline
\end{tabular}

Table 5. Specifications of the fabricated Induction generator
By considering efficiency and power factor influence in the design, minimum power, rotational speed and torque reqirements obtained for effective prime mover action are $9.698 \mathrm{~kW}, 1545 \mathrm{rpm}$ and $59.941 \mathrm{Nm}$, respectively (Table 6).

\begin{tabular}{|l|l|}
\hline Type of Prime mover & Turbine or Engine \\
\hline $\begin{array}{l}\text { Minimum Power } \\
\text { required (in Horsepower) }\end{array}$ & $13 \mathrm{HP}$ \\
\hline $\begin{array}{l}\text { Minimum Power } \\
\text { required (in kW) }\end{array}$ & $9.698 \mathrm{~kW}$ \\
\hline $\begin{array}{l}\text { The minimum Rotational } \\
\text { speed required }\end{array}$ & $1545 \mathrm{RPM}$ \\
\hline $\begin{array}{l}\text { Minimum Torque } \\
\text { required }\end{array}$ & $\begin{array}{l}59.941 \mathrm{Nm}(6.11 \\
\mathrm{kgm})\end{array}$ \\
\hline
\end{tabular}

Table 6. Minimum requirements for the prospective prime mover.

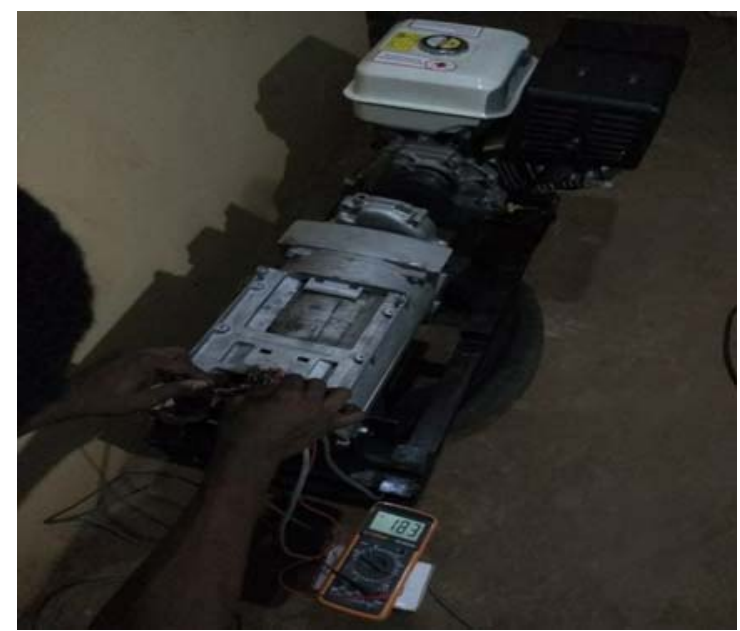

Fig. 9. Voltage testing of the alternator/generator

The results obtained for the two tests cases carried out on the fabricated generator are presented as shown in Tables 7 and 8, respectively. The current generated and recorded based on $2.3 \mathrm{~kW}$ load, 0.8 power factor and the corresponding line to neutral voltages for the phase 3 are given in Table 9. The results showed that a maximum speeds close to $2714 \mathrm{rpm}$ (under no laod) and $2439 \mathrm{rpm}$ (under load) were obtained. The speeds were somewhat close to the target speed of $3000 \mathrm{rpm}$. Maximum voltage of $189 \mathrm{~V}$ (no load) and $159 \mathrm{~V}$ (load) were obtained spaning the two cases of testing periods (Tables 7 and 8). These output voltages were somewhat close to the targetted voltage $(239.6 \mathrm{~V} \approx 240 \mathrm{~V})$. The first case test (during afternoon) under load $(2.3 \mathrm{~kW})$ showed a variation of voltage and current outputs for the four replicates within the range of 151 and $158 \mathrm{~V}$, 6.07 $\mathrm{A}$ and $6.35 \mathrm{~A}$, respectively. In the second case test (during evening under similar load), constant voltage and current of $158 \mathrm{~V}$ and $6.07 \mathrm{~A}$ were observed, respectively (Table 9). The amperage was somewhat close to the designed current (10.467 A). The outcomes of the two cases indicated that the power output (voltage and current) were been influenced by the nature of the environment. The outcomes further revealed that improvement in rotation speed from turbine/engine can result in increase in torque and hence the power output. 


\begin{tabular}{|c|c|c|c|c|}
\hline Time & 13.00 & 13.20 & 13.40 & 14.00 \\
\hline $\begin{array}{l}\text { No-load } \\
\text { speed (rpm) }\end{array}$ & 2644 & 2623 & 2572 & 2714 \\
\hline $\begin{array}{l}\text { Load speed } \\
(\mathrm{rpm})\end{array}$ & 2423 & 2439 & 2401 & 2426 \\
\hline \multicolumn{5}{|c|}{ No-load voltage (volts) } \\
\hline Phase 1 & 78 & 81 & 78 & 88 \\
\hline Phase 2 & 178 & 176 & 179 & 188 \\
\hline Phase 3 & 180 & 180 & 181 & 189 \\
\hline \multicolumn{5}{|c|}{ Load voltage (volts) } \\
\hline Phase 1 & 68 & 68 & 70 & 72 \\
\hline Phase 2 & 151 & 156 & 153 & 151 \\
\hline Phase 3 & 151 & 158 & 151 & 156 \\
\hline
\end{tabular}

Table 7. Generator's speed and voltage test results at hours of 13.00-14.00 GMT.

\begin{tabular}{|l|l|l|l|l|}
\hline Time & 19.00 & 19.20 & 19.40 & 20.00 \\
\hline $\begin{array}{l}\text { No-load } \\
\text { speed (rpm) }\end{array}$ & 2667 & 2696 & 2633 & 2609 \\
\hline $\begin{array}{l}\text { Load speed } \\
\text { (rpm) }\end{array}$ & 2400 & 2383 & 2390 & 2385 \\
\hline No-load voltage (V) \\
\hline Phase 1 & 88 & 81 & 85 & 81 \\
\hline Phase 2 & 179 & 178 & 180 & 173 \\
\hline Phase 3 & 184 & 181 & 173 & 181 \\
\hline Load voltage (V) & \multicolumn{5}{|l|}{} \\
\hline Phase 1 & 79 & 72 & 78 & 78 \\
\hline Phase 2 & 156 & 159 & 157 & 156 \\
\hline Phase 3 & 158 & 158 & 151 & 156 \\
\hline
\end{tabular}

Table 8 . Generator's speed and voltage test results at hours of 19.00-20.00 GMT.

\begin{tabular}{|l|l|l|}
\hline S/N & $\begin{array}{l}\text { Line to neutral } \\
\text { Voltage (V) }\end{array}$ & Current (Amps) \\
\hline \multicolumn{3}{|c|}{ Test results at hours of $13.00-14.00$ GMT. } \\
\hline 1 & 151 & 6.35 \\
\hline 2 & 158 & 6.07 \\
\hline 3 & 151 & 6.35 \\
\hline 4 & 156 & 6.14 \\
\hline \multicolumn{3}{|l|}{ Test results at hours of 19.00-20.00 GMT. } \\
\hline 1 & 158 & 6.07 \\
\hline 2 & 158 & 6.07 \\
\hline 3 & 158 & 6.07 \\
\hline 4 & 158 & 6.07 \\
\hline
\end{tabular}

Table 9. Current and line to neutral voltage based on the connected load

In the process of testing the alternator, some problems were encountered. The alternator was driven at over $2000 \mathrm{rpm}$ without producing any power due to burnt stator windings caused by the short-circuiting of the coils. The fault was corrected by changing rewinding type from delta to star where the line voltage was made the same as the phase voltage. Other induction generator faults and failures encountered included: unfavourable operating conditions (electrical, mechanical or environmental) that can dramatically shorten the life of three-phase stator winding. The winding failures were rectified by following the standard maintenance measures [35]. On this basis, other failures due to poor insulation, voltage surge, thermal deterioration of insulation, phase damage, winding damage and locked rotor can be rectified.

\section{CONCLUSION}

As the generator is a vital part of the electricity generating ability of a power plant, it is important to choose the generator based on its maintainability, efficiency, price and load bearing capacity. Induction generators are best for micro-power installations because they can produce power efficiently at varying rotor speeds. Besides, they are mechanically and electrically simpler in design than other generating types. They are also more rugged since they require no brushes or commutators. This study has exposed that the generator can be bought brand new or a scrap generator can be rewound to desired power specifications. Besides economy of rewind, there are more other advantages including loading flexibility, power rating flexibility and ease of repair. It was realized from the study that the generating ability of any power station depends on the cordiality of the relationship between the prime mover and the generator. For optimum efficiency of the induction generator, it is recommended that the turbine or the prime mover to be coupled should have at least no-load speed rating of $3000 \mathrm{rpm}$. The loads connected across the mains should be less than the rated wattage (5 $\mathrm{kW}$ ) to prevent the heating up and burning of the windings.

\section{REFERENCES}

[1] Whitney, Gene. Fossil Fuel, Microsoft ${ }^{\circledR}$ Encarta ${ }^{\circledR}$ [DVD]. Redmond, WA: Microsoft Corporation, 2008.

[2] Ali, Y.: The shortage of natural gas for power generation in Nigeria: counting the costs, Premium Times, accessed 20 July 2017, 2017.

[3] Engineering ToolBox: Electric Motors - Power and Torque vs. Speed, https://www.Engineering toolbox.com/electrical-motors-hp-torque-rpmd 1503.html/, accessed 14:10:2018, 2009.

[4] TACS: General layout of electricity networks, http:/www.tacs.eu/Analyses/Energy/electricalgrid.htm/, accessed 14:10:2018, 2016.

[5] Azhumakan, Z, Murat, M, Balzhan, A.: Selection of Generator for the Micro Hydro Power Plant, American-Eurasian Journal of Scientific Research, 8 (3) p.p. 104-108, 2013

[6] Bhatti, T.S., Bansal, R.C., Kothari D.P.: Small Hydro Power Systems, Dhanpat Rai and Sons, Delhi, India. 2004.

[7] Lukutin, B.V., Obukhov, S.G., Shandarova, E.B.: Autonomous power supply from the micro hydropower plant. - Tomsk: STT, pp: 12. 2001.

[8] Alternative Energy: Microsoft ${ }^{\circledR}$ Encarta ${ }^{\circledR} 2009$ [DVD], Redmond, WA: Microsoft Corporation, 2008, 2009.

[9] Izah, S., Ohimain, E., Angaye T., Potential Thermal Energy from Palm Oil Processing Solid Wastes in Nigeria: Mills Consumption and Surplus Quantification, British Journal of Renewable Energy, 1, p.p. 39-45, 2016. 
[10] Lukutin, B.V., Sipailov, G.A.: Using mechanical energy from the renewable Natural sources for the power supply of autonomous consumers, Frunze: Publishing House of the Ilim, 1987.

[11] Muhammad , A., Tjahjono, H., Meta, R.: Analysis of palm biomass as electricity from palm oil mills in North Sumatera, Energy Procedia, 47, p.p. 166172, 2014.

[12] Oladosu, O, Kareem, B, Akinnuli, O, Asafa, B.: Application of computer-aided design for palm kernel shell steam boiler", Leonardo Electronic Journal of Practices and Technologies, 30, p.p. 87104, 2016.

[13] Sulaiman, N., Abdullah, H., Gerhauser, A. S.: An outlook of Malaysian energy, oil palm Industry and its utilization of wasted as useful resources, Biomass and Bioenergy, 35, p.p. 3775-3786, 2011.

[14] Simoes, M.G., Farret, F. A.: Renewable energy systems: design and analysis with induction generators, CRC Press, New York, 2004.

[15] Small-scale generation: http://www.worldbank.org /fpd/publicpolicyjournal/, accessed 10:04: 2013.

[16] CK-12: How a Coal Power Plant Works.: https:// www.ck12.org/earth-science/coal-power/rwa/ How -a-Coal-Power-Plant-Works/ accessed 14:10: 2018, 2018.

[17] Christopher, F., Seth, D.: Will renewable energy come of age", Encarta yearbook, October 1998, 1998

[18] International Energy Agency (IEA): Executive summary,p.p. 5, 2011.

[19] Top DIY Solar Panels: What is a Renewable Energy Source, http://topdiysolarpanels.net/whatis-a-renewable-energy-source/, accessed 14:10: 2018, 2013.

[20] Upadhayay, S., Evaluating the effectiveness of micro-hydropower projects in Nepal. San Jose State University, SHSU Scholar Works, 2009.

[21] United Nations: Sustainable energy for all, "about us, http://www. sustainableenergyforall.org/aboutus/ accessed 3:2:2013, 2013.

[22] Wikipedia: Electricity generation, :https://en. wikipedia.org/wiki/Electricity_generation/, accessed 14:10: 2018.

[23] Electrical Engineering Community: What is an Electric Generator? http://engineering.electricalequipment.org/electrical-distribution/what-is-anelectric-generator.html/ accessed 14:10:2018, (2013).

[24] Bansal, R.C.: Three-Phase Self-Excited Induction Generators (SEIG): An Overview, IEEE Trans. Energy Conversion, 20(2), p.p. 292-299, 2005.

[25] Agus, S..: Influence of excitation capacitor location to the output of low-power single-phase induction generator, AIP Conference Proceedings, 1977.

[26] Bansal, R.C., Bhatti, T.S., Kothari, D.P.: A bibliographical survey on induction generators for application of non-conventional energy systems, IEEE Trans. Energy Conversion, 18(3), p.p. 433439, 2003.

[27] Engineering ToolBox: Electrical Induction Motors Synchronous Speed, https://www.Engineering toolbox.com/synchronous-motor-frequency-speed- d 649.html/ accessed 14:10: $2018,2004$.

[28] Horowitz, P., Hill, W.: The art of electronics (3rd Ed.). Cambridge University Press, 2015.

[29] All About Circuits: Three-phase-y-deltaconfigurations, https://www.allaboutcircuits.com/ textbook/alternating-current/chpt-10/three-phase-ydelta-configurations/ accessed 14 October, 2018.

[30] Engineering ToolBox: Electrical Motors - Full LoadAmps.,https://www.engineeringtool box.com/ elctrical-motor-full-load-current-d 1499.html/, accessed 14:10: 2018, 2009.

[31] Edvard, C.: Basic three-phase power measurements explained, https://iaeimagazine.org /magazine /2017/05/16/basic-three-phase-powermeasurements-explained/ accessed 14:10: 2018, 2018.

[32] Smith, R.J., Dorf, R.C.: Circuits, Devices and Systems, 5th edition, John Wiley \& Sons, Ltd, Chichester, 2004.

[33] Engineering ToolBox: Power Factor - Inductive Load, https://www.engineeringtoolbox.com/power factor-electrical-motor-d 654.html/, accessed 14:10:2018, 2004.

[34] Engineering ToolBox: Slip in electrical induction motors, https://www.engineeringtoolbox.com/ electrical-motor-slip-d_652.html/, accessed 28:10: 2018, 2004.

[35] The Electro-Mechanical Authority: Typical Failures in Three-Phase Stator Windings, https://www.easa.com/resources/booklet/typicalfailures-three-phase-stator-windings/, accessed 14:10:2018, 1985.

\section{AKNOWLEDGEMENT}

Tetfund Nigeria is acknowledged for supporting this research under grant Ref: VCPU/TETFund/155

Authors: Professor Buliaminu Kareem ${ }^{1}$ PhD, Assoc. Professor T. Ewetumo ${ }^{2}$ PhD, Asst. Professor M. K. Adeyeri $^{1}$ PhD, Assoc. Professor A. Oyetunji ${ }^{3}$ PhD, Master S. T. Olowookere ${ }^{1}$. Federal University of Technology Akure, School of Engineering and Engineering Technology, ${ }^{1}$ Department of Industrial and Production Engineering, ${ }^{2}$ Department of Physics, ${ }^{3}$ Department of Metalurgical and Materials Engineering, P.M.B. 704 Akure, Akure/Ilesa Express way, 340001, Akure, Nigeria, Phone.: +234 8033737251 .

E-mail: bkareem@,futa.edu.ng tewetumo@futa.edu.ng mkadeyeri@futa.edu.ng aoyetunji@futa.edu.ng karbi12002@yahoo.com 